\title{
FOUR NEW NEOTROPICAL SPECIES AND A NEW COMBINATION OF URERA (URTICACEAE)
}

\author{
Victor W. SteinManN \\ Instituto de Ecología, A.C., Centro Regional del Bajío, Apdo. postal 386 \\ 61600 Pátzcuaro, Michoacán, México
}

\begin{abstract}
The pantropical genus Urera (Urticaceae) has been taxonomically neglected in present times. Approximately ten species of the genus occur in Mexico with an additional four in Central America. In this article, taxonomically useful characters for the Mexican and Central American taxa are provided and some of the taxonomic problems associated with these species are discussed. Four new species are proposed (Urera glabriuscula, U. martiniana, U. pacifica, and U. rzedowskii), and a new combination (Urera verrucosa) is made.
\end{abstract}

Key words: Central America, Mexico, taxonomy, Urera, Urticaceae.

\section{RESUMEN}

Urera es un género pantropical que no ha tenido atención reciente por parte de los taxónomos. Para México se conocen alrededor de diez especies y de Centroamérica otras cuatro. En el presente artículo se ofrece información sobre los caracteres de importancia taxonómica para las especies mexicanas y centroamericanas, así como una discusión sobre algunos de los problemas taxonómicos que existen con relación a estas plantas. Además, se describen cuatro especies nuevas para la ciencia (Urera glabriuscula, U. martiniana, U. pacifica y $U$. rzedowskii) y se propone la combinación $U$. verrucosa.

Palabras clave: Centroamérica, México, taxonomía, Urera, Urticaceae.

\section{INTRODUCTION}

Like so many plant groups, the genus Urera Gaud. (Urticaceae) has been relatively neglected in modern times. Despite its relatively small size (35 species according to Friis, 1993; 35-75 according to Pool, 2001), the most recent monographs 
are the outdated treatments by Weddell $(1856,1869)$. Since then, various species have been described and floristic accounts have been published, but there exists a general lack of understanding about the genus, and over the years there has been no general consensus even on the application of names. Killip (1960) notes in particular, "the American species of Urera are greatly in need of taxonomic revision," and Burger (1977) shares a similar view, stating that, "the neotropical species are in need of a careful monographic study" and that the genus presents "some of the most perplexing patterns of variation that the neotropical flora has to offer."

Like most Urticaceae, Urera prospers in relatively mesic tropical habitats. The genus is pantropical in distribution, and many species favor open, disturbed sites. Standley (1922) recognized only three species for Mexico, one of which, Urera microcarpa Wedd., is now considered to belong to the genus Gyrotaenia Griseb. (Fawcett and Rendle, 1914; Adams, 1972). In the Flora of Guatemala (Standley and Steyermark, 1952), six species where recognized; while Burger (1977) treated four for Costa Rica; and Pool (2001) had six for Nicaragua. I believe that about ten species of Urera are actually present in Mexico, and there are probably an additional four species in Central America. As the previous comments by Friis and Burger imply, further research is still required to fully clarify all of the taxonomic problems existing for the Mexican and Central American species. However, some advances can be made at present, and the purpose of this article is to discuss taxonomically useful characters, elaborate on some of the problems related to the Mexican and Central American members, propose four new species of Urera, and make one new combination.

\section{METHODOLOGY}

During the course of this study over 400 collections from Mexico and Central America housed at the following herbaria were examined: ARIZ, CAS, DS, BM, ENCB, IBUG, IEB, K, MEXU, NY, P, POM, RSA, UC, UCR, US, XAL, ZEA. In addition, original descriptions of all of the proposed binomials occurring in or close to these areas were consulted, and type material, either photos or the actual specimens, for most of these was examined.

\section{TAXONOMIC CONSIDERATIONS}

Urera are shrubs or small trees with alternate leaves, and although the majority of species are dioecious, there are a few monoecious members. Some possess spines 
on the stems and leaves, but these are usually lacking. Leaf shape, in particular that of the base, and variation in venation patterns are in many instances valuable taxonomic features. Conspicuous cystoliths are present on both surfaces of the leaves, and the shape and arrangement of cystoliths, especially on the upper surface, are taxonomically important. The same is true for pubescence, in particular the presence and distribution of urticating hairs (i.e., relatively long, stiff, straight, translucent, swollen-based, and highly stinging trichomes). The inflorescences are always highly divided, dichotomously or irregularly branched panicles. The relative length of the inflorescences, as well as the length of the primary peduncle, are in some instances useful for distinguishing among species.

For the most part, the minute flowers of Urera are uniform and appear to provide relatively few taxonomically important characters. However, merosity of the staminate flowers appears to be a significant and useful distinguishing feature. With few exceptions (e.g., Urera glabriuscula described below), staminate flowers are either 4-merous or 5-merous depending on the species. Pool (2001) also mentioned the unusual feature of ovate staminate buds with acutely pointed tips for Urera simplex Wedd. Staminate buds are otherwise wheel-shaped and flattened. Pistillate flowers also provide relatively few taxonomically important characters, but the length of the pedicel and the degree to which the ovary and fruit is enveloped by the perianth do appear useful. Another helpful trait is whether the female flower is erect or bent away in relation to the pedicel. Fruit color, as well as whether it is the perianth or the receptacle that become swollen and fleshy, represent other systematically important diagnostic features.

While some taxa are cleanly separable, the Mexican and Central American species are on the whole subject to the existence of many intermediate or otherwise ambiguous specimens. This problem was emphasized by Burger (1977) who noted that in some instances only $90 \%$ of the material could be identified with confidence. Further compounding the taxonomy of these plants is the observation that few traits are constant for a species, and exceptions are the norm. In some cases, determination is possible only by a consensus of various taxonomically important traits as opposed to any definitive and absolute feature, and unfortunately a certain degree of subjectivity can be required.

There are additional difficulties associated with this genus. Determining specimens sometimes is problematic due to the availability of only incomplete material. Because most species are dioecious and because flowering and fruiting are temporally separated, collections possessing staminate flowers, pistillate flowers, and fruits together are rare. Moreover, the species are wind-pollinated and more than one often are present in the same area, and I suspect hybridization occurs. However, whether intermediate specimens are actually hybrids or the result of some other phenomenon must await future study. 
Traditionally, much of the Mexican and Central American material of Urera has been routinely identified as Urera caracasana (Jacq.) Griseb., a classic "garbage-bin species." Little attention has been paid to the observation that many discordant elements are often present under this name in herbaria. The irony here is that U. caracasana only extends as far as Panama (Pool, 2001), and all of the plants from Costa Rica northward actually belong to other species. One of the most common and widespread of these is Urera corallina (Liebm.) Wedd. This species is also one of the most similar to "true" U. caracasana. Pool (2001) distinguished $U$. caracasana from $U$. corallina by the possession of smaller achenes, differently colored fruits, and a fruiting perianth that only partially covers the achene, and I agree with her characterization. In addition, one of the most striking differences between these species is that in Urera corallina the pistillate flowers are on welldeveloped pedicel, and it is the perianth that becomes swollen and succulent in fruit; whereas in $U$. caracasana the pistillate flowers are subsessile, and it is actually the receptacle that swells and becomes fleshy. The two species are otherwise alike, especially vegetatively, and both possess strictly 4-merous staminate flowers.

\section{NEW SPECIES AND COMBINATION}

Urera glabriuscula V.W. Steinm., sp.nov. Type: Mexico. Veracruz: mpio. San Andrés Tuxtla, Volcán San Martín, encinar, 1300 m, 2 IV 1985, Cedillo 3175 (holotype IEB; isotype MEXU).

Frutex vel arbor 2-12 m alta, dioecia; stipulae late subulatae, 0.6-0.8 cm longae, apice bifido, petioli 3-9 $\mathrm{cm}$ longi, laminae foliorum lanceolatae vel ellipticae, (4.5)7-19(26.5) cm longae, (2.5)3-7.5 cm latae, apice attenuato-acuminato, basi cuneata, margine minute sinuato-dentato vel minute crenato, saepe subintegro, 3nerviae, supra et subtus glabrae; inflorescentia paniculata, $1.5-4.5 \mathrm{~cm}$ longa, ramosissima, unisexualis; flores staminati vulgo 3-5 in fasciculis, pedicelli angusti, 0.9-1.9 mm longi, tepala 4 vel 5, lobi ovati vel oblongi, 0.8-1.9 mm longi, stamina 4 vel 5, fila 1.6-2.1 mm longa, antherae 0.8-1.0 mm longae; flores pistillati in fasciculis, pedicelli (0.2)1.1-1.3 mm longi, perianthium 0.9-1.3 mm longum, glabrum, ovarium tectum, stigma penicillatum, 0.2-0.4 mm longum; perianthium fructiferum carnosum, 1.4-1.8 mm longum, aurantiacum vel rubrum, achenium 0.8-1.0 mm longum.

Trees or shrubs 2-12 m tall, dioecious, bark smooth, light white to yellow gray; branchlets strigulose when young, glabrescent; stipules narrowly ovate, 0.6$0.8 \mathrm{~cm}$ long, bifid at the apex, petioles slender, 3-9 cm long, strigulose when young, glabrescent, lamina lanceolate to elliptic, (4.5)7-19(26.5) cm long, (2.5)3-7.5 cm wide, 
apex attenuate-acuminate, base cuneate, margin shallowly sinuate-dentate to shallowly crenate, often becoming subentire in age, the teeth mostly rounded, strongly 3 -veined from the base, the 2 basal lateral veins prominent and often running almost parallel to the midvein at midleaf, distance between the basal and second pairs of veins greater than the distance between the second and third pairs of veins, primary veins scarcely elevated on the lower surfaces, secondary veins slightly sunken, often uniting the midvein with the lateral veins, upper and lower surfaces glabrous, cystoliths of the upper surface mostly punctiform but with scattered shortly elongated cystoliths intermingled, essentially evenly arranged over the surface, cystoliths of the lower surface elongated, arranged in a conspicuously reticulate pattern above the veins; inflorescences on the older branches, unisexual, staminate represented by diffuse panicles 1.5-2.5 cm long, pistillate represented by diffuse panicles (1.5)2.5-4.5 cm long, primary peduncle $0.5-2.2 \mathrm{~cm}$ long, rachis puberulent with short, stiff hairs ca. $0.1 \mathrm{~mm}$ long; staminate flowers mostly in fascicles of 3-5 flowers at the ultimate tips of the inflorescence branches, pedicel slender, 0.9-1.9 mm long, bud wheel-shaped and flattened, tepals 4 or 5 , outer surface glabrous to puberulent, lobes ovate to oblong, 0.8-1.9 mm long, stamens 4 or 5, filaments $1.6-2.1 \mathrm{~mm}$ long, anthers $0.8-1.0 \mathrm{~mm}$ long; pistillate flowers in fascicles at the ultimate tips of the inflorescence branches, bent away from the pedicels, pedicels (0.2)1.1-1.3 mm long, perianth 0.9 to $1.3 \mathrm{~mm}$ long, glabrous, tightly enveloping the entire ovary, stigma penicillate, $0.2-0.4 \mathrm{~mm}$ long; fruits with the perianth becoming fleshy, 1.4-1.8 $\mathrm{mm}$ long, orange to red, achene lenticular, nearly circular in outline, $0.8-1.0 \mathrm{~mm}$ long, pointed at the apex.

Southern Mexico in the states of Oaxaca, Veracruz, Tabasco, and Chiapas; Guatemala. It occurs in perennial tropical rain forest and cloud forest, rarely entering tropical subdeciduous forest and mesic oak forest; 130-1350 m. Collected reproductive nearly throughout the year with flowering from December to May and fruiting from February to October.

Vegetatively, this is one of the most distinctive species of Urera due to its glabrescent leaves that often develop a subentire or very shallowly crenate margin in age and have a particularly long, acuminate tip; also noteworthy is the presence of three conspicuous main veins that are scarcely elevated above the lower surface of the leaf. The species is unusual because the staminate flowers can be either 4-merous or 5-merous. Merosity otherwise appears quite constant in the Mexican and Central American Urera.

Urera glabriuscula is common in southern Mexico and has frequently been identified as Urera elata (Sw.) Griseb. However, I am in agreement with both Adams (1972) and Pool (2001) that Urera elata is endemic to Jamaica. Urera glabriuscula can be distinguished from this species by the characteristics of the leaves discussed above. In Urera elata, the leaves are much more conspicuously 
toothed, and are more pubescent, frequently with urticating hairs on the underside and petiole. Also, the pistillate flower is bent away in relation to the pedicel in $U$. glabriuscula, whereas it is straight and erect in U. elata.

Common names: berenjenilla (González \& Garza 5358), coyalillo (González \& Garza 5358), hueva de cangreja (Guadarrama \& López 779), hueva de cangrejo (Ibarra 393, 655, 1224, 1492, 2252, 2268, Sinaca 185), huevo de cangrejo (Estrada 1693), huevo de peje (González \& Pérez ES-2244), palo de agua (Calzada 10660), panza de toro (Ramos \& Guadarrama 668), palo verde (González \& Garza 2080), yashanal zulsinte (Shilom 7282).

Additional specimens examined. GUATEMALA. Izabal: Santo Tomás de Castilla, on rd past Las Escobas going to the Guatel tower, $88^{\circ} 38^{\prime} \mathrm{W}, 15^{\circ} 42^{\prime} \mathrm{N}$, Marshall et al. 412 (NY); W of Santo Tomás de Castilla, rd to the antennas on

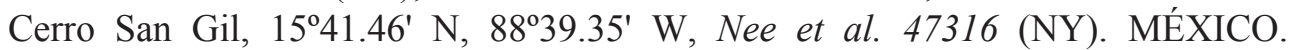
Chiapas: mpio. Ocozocuautla, $20 \mathrm{mi} \mathrm{N}$ of Ocozocuautla, Breedlove 10003 (ENCB); mpio. Ocozocuautla, Selva de Ocote, $32 \mathrm{~km} \mathrm{NW}$ of Ocozocuautla, Breedlove 27479 (DS); mpio. Ocozocuautla, $45 \mathrm{~km} \mathrm{~N}$ of Ocozocuautla, above the community and lake of Malpaso, Breedlove 32842 (DS, MEXU); mpio. Berriozábal, $13 \mathrm{~km} \mathrm{~N}$ of Berriozábal near Pozo Turipache and Finca El Suspiro, Breedlove \& Smith 31520 (DS, ENCB, MEXU); en los alrededores de la zona arqueológica de Palenque, Cabrera 1950 (MEXU, XAL); $9 \mathrm{~km}$ al W de la Ciudad de Palenque, en los alrededores de la zona arqueológica de Palenque, Cabrera 5611 (MEXU, XAL), ibid., Cabrera 7001 (MEXU, XAL); $25 \mathrm{~km}$ al S de la desviación a Chancala, sobre la carr. Palenque-Ocosingo, Cabrera 5645 (MEXU); mpio Macuspana, Parque

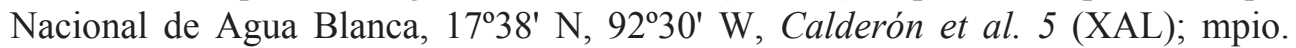
Ocozocuautla, Reserva del Ocote, La Cueva, al NW del Rancho Corocito, Calzada 9739 (ENCB, IBUG, IEB, MEXU); mpio. Salto del Agua, Agua Azul, Martínez 101 (ENCB); Palenque ruins, hills E of entrance, McPherson 743 (ENCB); municipio de Ishuatan, orilla de carr. 195, $45 \mathrm{~km}$ al N de Pichucalco, Gliessman 77-2 (ENCB); 6 mi S of Palenque, Lathrop 6550 (DS, RSA); 2 mi N of Pueblo Nuevo Solistahuacán, Lathrop 6768 (DS, RSA); mpio. Ocosingo, 2 km al N de Naja, camino a Chancala, Martínez 18767 (ARIZ, CAS, IBUG, IEB); mpio. Ocozocuautla,

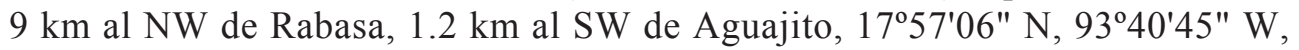
Ochoa 3842 (XAL); mpio. Ocozocuautla, $9 \mathrm{~km}$ al NW de Rabasa, $1 \mathrm{~km}$ al SW de Aguajito, 16²57'32" N, 9340'48" W, Ochoa-Gaona 3899 (MEXU); Ocozocuautla, Reserva Ecológica "El Ocote" Ortiz 946 (CAS); Palenque Archeological Site, 3 mi $\mathrm{S}$ of Palenque, Thorne \& Lathrop 40576 (DS, RSA); mpio. Bochil, along the river E of Bochil, Shilom 2582 (DS, ENCB); mpio. Tenejapa, Ojo de Agua, Shilom 7282 (CAS, MEXU); mpio. Ocozocuautla, camino Ciprés a Horizonte, Vázquez 978 (XAL). Oaxaca: distr. Juchitán, mpio. Santa María Chimalapa, San Antonio Nuevo 
Paraíso, 1708'49" N, 94²0'04" W, Rivera 109 (MEXU); distr. Tehuantepec, mpio. Guevea de Humboldt, Cerro Picacho, $8.3 \mathrm{~km}$ al N de Guevea de Humboldt, Torres 9133 (MEXU). Tabasco: mpio. Teapa, Sierra El Madrigal, Centro Regional Univ. del SE, Estrada 1693 (NY); mpio. Tacotalpa, $0.2 \mathrm{~km}$ abajo (NW) de, y antes de entrar a Tapijulapa, hasta $0.5 \mathrm{~km}$ arriba del camino por el arroyo a pie, Cowan et al. 3493 (CAS, ENCB, MEXU, XAL); mpio. Teapa, Cerro del Coconá, Curiel 3 (ENCB, MEXU); Mpio. Teapa, Cerro del Madrigal, $3 \mathrm{~km}$ al E de Teapa, Fernández et al. 2204 (BM, ENCB, MEXU, NY); mpio. Teapa, en la base del Cerro del Madrigal, NE del Centro Regional de Puyacatengo, Galindo 2 (XAL); mpio. Macuspana, en el Balneario "Agua Blanca" Guadarrama 614 (ENCB, IEB, MEXU, XAL); mpio. Tacotalpa, Grutas de Oxolotán a $2 \mathrm{~km}$ a la izquierda, Guadarrama 872 (NY); mpio. Tacotalpa, en Sierra Poaná a $500 \mathrm{~m}$ de Ejido Xicoténcatl, Guadarrama \& López 779 (ENCB, IEB, MEXU); $11 \mathrm{mi}$ NE of Pichucalco on the rd to Teapa, at El Azufre, Hansen et al. 1697 (RSA); mpio. Tacotalpa, Grutas, $4 \mathrm{~km}$ al SE de Tapijulapa rumbo a Oxolotán, 17²6'30" N, 92 45'30" W, Hernández 140 (ENCB); mpio. Teapa, arriba del Cerro del Coconá, Magaña 1172 (ENCB, MEXU, XAL); mpio. Macuspana, en el centro recreativo de Agua Blanca, Magaña et al. 1209 (ENCB, IBUG, MEXU, XAL); mpio. Teapa, Cerro del Madrigal subiendo por el oeste, Ramos \& Guadarrama 668 (ENCB, MEXU, XAL); ladera kárstica al S de Los Azufres, Rico 711 (MEXU); mpio. Macuspana, Agua Blanca, Ventura 20944 (ENCB, NY); mpio. Teapa, Cerro del Madrigal, frente al edificio de Puyacatengo, Ventura 20686 (ENCB, NY); mpio. Teapa, El Madrigal, Ventura 20987 (ENCB, MEXU, XAL); mpio. Teapa, $3 \mathrm{~km}$ al E de Teapa rumbo a Tapijulapa, Zamudio 44 (ENCB, MEXU, XAL). Veracruz: mpio. San Andrés Tuxtla, camino Ejido Santa Rosa-Ruiz Cortínes, S del Volcán San Martín, 18³3' N, 95¹2' W, Avendaño \& Narave 1203 (ENCB, IEB, UC); mpio. San Andrés Tuxtla, lado SE del Volcán San Martín Tuxtla, Beaman \& Álvarez 5980 (NY); cima del Volcán de San Martín, Calzada 73 (CAS, MEXU); Estación Biológica de Los Tuxtlas, $18^{\circ} 35^{\prime} \mathrm{N}, 95^{\circ} 01^{\prime} \mathrm{W}$, Calzada 772 (BM, K, MEXU); mpio. San Andrés Tuxtla, camino al cráter del Volcán San Martín Tuxtla, lado S, 18³4' N, 95²12' W, Calzada 10660 (IEB, UC, XAL); mpio. Mecayapan, cima del Volcán San Martín Pajapan, al S del Ejido La Valentina, Calzada 10915 (XAL); mpio. Catemaco, ladera S del Cerro Jegla, al N del Rancho Los Naranjos, entrada por la carr. Catemaco-Dos Amates, Calzada 11561 (IEB, MEXU, XAL); mpio. San Andrés Tuxtla, Sierra de los Tuxtlas, al N de San Andrés Tuxtla, senda para Cerro Baxin, Calzada 11924 (IEB, XAL); mpio. San Andrés Tuxtla, Volcán de San Martín Tuxtla, $20 \mathrm{~km}$ al N de San Andrés Tuxtla, Cedillo 2971 (ENCB, MEXU, XAL); mpio. San Andrés Tuxtla, Estación de Biología Tropical Los Tuxtlas, Lote 67, Cedillo 3519 (IEB, MEXU); mpio. San Andrés Tuxtla, $13 \mathrm{~km} \mathrm{~N}$ of San Andrés Tuxtla, SE side of Volcán San Martín, 1833'30" N, 95²12' W, Diggs et al. 2690 (NY, XAL); 
Estación Biológica del los Tuxtlas, camino a la Laguna Escondida, $18^{\circ} 35^{\prime} \mathrm{N}, 9^{\circ} 01^{\prime}$ W, Dillon et al. 1778 (NY, XAL); km 5-6 del camino Plan de Arroyos-Álvaro

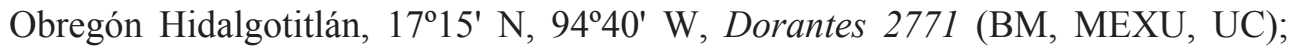
region of San Andrés Tuxtla, NW of Catemaco, near Cerro Nopo and Cerro Campana (between Cerro Mono Blanco and Cerro Tapalcapan), Dressler \& Jones 22 (BM, MEXU, NY, UC); km 7 carr. Coyame-Catemaco, González \& Garza 2080 (MEXU); $6.5 \mathrm{~km}$ de Santiago Tuxtla y $3.6 \mathrm{~km}$ camino al Cerro del Vigía, González \& Garza 5358 (MEXU), ibid., González \& Garza 5363 (MEXU); mpio. San Andrés Tuxtla, Estación de Biología Tropical Los Tuxtlas, lote 67, Ibarra 393 (MEXU, XAL); mpio. San Andrés Tuxtla, Estación de Biología Tropical Los Tuxtlas, El Vigía, Ibarra 655 (MEXU, XAL); mpio. San Andrés Tuxtla, Estación de Biología Tropical Los Tuxtlas, lote 67, Ibarra 1224 (ENCB, MEXU, XAL), ibid., Ibarra 1492 (ARIZ, MEXU, XAL), ibid., Ibarra 2252 (ENCB, MEXU, XAL); mpio. San Andrés Tuxtla, Estación de Biología Tropical Los Tuxtlas, lote 69, Ibarra 2268 (ENCB, MEXU, XAL); mpio. Catemaco, Estación de Biología Tropical "Los Tuxtlas" Lorence 3295 (BM, MEXU); mpio. Yecuatla, rd from Naolinco to Misantla, $13 \mathrm{~km}$ by rd S of turnoff to Yecuatla and $6 \mathrm{~km}$ by rd $\mathrm{N}$ of Paz de Enríquez, 1951' N, 96²48'30" W, Nee et al. 26355 (NY, XAL); Volcán San Martín, 18³5' N, 9509' W, Nevling \& Gómez-Pompa 2504 (CAS, ENCB, MEXU, NY); mpio. Catemaco, 18 $32^{\prime} 27^{\prime \prime} \mathrm{N}, 95^{\circ} 02^{\prime} 55^{\prime \prime} \mathrm{W}$, Palma 547 (XAL); mpio. Catemaco, $2 \mathrm{~km}$ antes de El Bastonal, 18 23'00" N, 94 56'00" W, Ramírez \& Vázquez 726 (XAL); El Amate cerca Coyame, Rosas 1383 (BM, CAS, MEXU); mpio. San Andrés Tuxtla, Estación de Biología Tropical Los Tuxtlas, Cerro Lázaro Cárdenas, lote 71, Sinaca 185 (MEXU); mpio. Hidalgotitlán, brecha Hnos. Cedillo-La Escuadra, 17²16' N, 94937' W, Vázquez 524 (BM, MEXU, XAL); mpio. Jesús Carranza, $2 \mathrm{~km}$ al N del Poblado 2, Ejido F.J. Mina, 17¹6' N, 9440' O, Vázquez et al. V-2481 (XAL); mpio. Yecuatla, El Cajón, Ventura 4811 (ARIZ, CAS, ENCB); mpio. Santiago Tuxtla, La Laguna, Ventura 14906 (ENCB, MEXU, NY).

Urera martiniana V.W. Steinm., sp. nov. Type: Mexico. Querétaro: mpio. Jalpan, near the border with San Luis Potosí, about $1.3 \mathrm{~km}$ (by air) SE of La Cercada along the trail to La Mesa, ca. $21^{\circ} 29^{\prime} 00^{\prime \prime} \mathrm{N}, 9^{\circ} 08^{\prime} 30^{\prime \prime} \mathrm{W}$, disturbed area in bosque mesófilo de montaña, 1200 m, 24 IX 2002, Steinmann \& Zamudio 2789 (holotype IEB; isotype MEXU).

Frutex 1-4 m alta, monoecia; stipulae subulatae, $1.1-1.3 \mathrm{~cm}$ longae, apice bifido, petioli (2.5)5.5-19 cm longi, foliorum laminae ellipticae vel ovatae, $12-28 \mathrm{~cm}$ longae, (3.5)5-14 cm latae, apice acuto vel acuminato, basi rotundata vel cuneata, margine dentato vel dentato-serrato, 3-nerviae, supra parce strigosae, glabratae, subtus pilosae vel puberulae, saepe glabratae; inflorescentia paniculata, $2-4 \mathrm{~cm}$ longa, ramosissima, 
unisexualis vel bisexualis; flores staminati numerosi in fasciculis, pedicelli angusti, 0.9-2.3 mm longi, tepala 5, lobi ovati vel subdeltoidei, 1.2-1.6 mm longi, stamina 5, fila 1.6-2.2 $\mathrm{mm}$ longa, antherae $0.7-1.0 \mathrm{~mm}$ longae; flores pistillati aggregati, pedicelli $0.2-0.5 \mathrm{~mm}$ longi, perianthium $0.4-0.7 \mathrm{~mm}$ longum, glabrum, ovarium expositum, stigma penicillatum, 0.1-0.2 mm longum; perianthium fructiferum carnosum, aurantiacum, achenium 0.8-1.1 mm longum.

Shrubs 1-4 m tall, monoecious; branchlets strigose to shortly hispid or puberulent; stipules subulate to narrowly ovate, $1.1-1.3 \mathrm{~cm}$ long, bifid at the apex, petioles slender, (2.5)5.5-19 cm long, with pubescence like that of the branchlets, urticating hairs also often present, lamina elliptic to ovate, 12-28 cm long, (3.5)5$14 \mathrm{~cm}$ wide, apex acute to acuminate, base rounded to cuneate, margin dentate to dentate-serrate, teeth acute, strongly 3 -veined from the base, primary and secondary veins conspicuously elevated on the underside, veins strigose to hispid, often with urticating hairs, upper surface sparsely strigose when young, glabrescent, lower surface pilose to puberulent between the veins, often glabrescent, cystoliths of the both surfaces punctiform and essentially evenly arranged over the surface; inflorescences in the axils of leaves of new growth, bisexual with a few clusters of staminate flowers in a predominantly pistillate inflorescence or unisexual with the staminate inflorescences arising from the lower nodes and the pistillate inflorescences in the upper nodes, highly branched panicles $2-4 \mathrm{~cm}$ long, primary peduncle 1.1$2.4 \mathrm{~cm}$ long, rachis puberulent-strigose or shortly hispid, often with scattered urticating hairs; staminate flowers numerous in dense fascicles at the ultimate tips of the inflorescence branches, pedicel slender, 0.9-2.3 mm long, bud wheel-shaped and flattened, tepals 5 , outer surface puberulent and sometimes with urticating hairs, lobes ovate to almost deltoid, 1.2-1.6 mm long, apex obtuse with a minute, subapical protuberance, stamens 5, filaments $1.6-2.2 \mathrm{~mm}$ long, anthers $0.7-1.0 \mathrm{~mm}$ long; pistillate flowers in highly abbreviated shoots at the ultimate tips of the inflorescence, pedicels $0.2-0.5 \mathrm{~mm}$ long, perianth $0.4-0.7 \mathrm{~mm}$ long, glabrous, covering only the lower portion of the achene, stigma penicillate, 0.1-0.2 $\mathrm{mm}$ long; fruits with the perianth becoming fleshy, 1.1-1.4 mm long including the exserted achene, orange, achene lenticular, suborbicular in outline, 0.8-1.1 mm long, pointed at the apex.

Endemic to the Sierra Madre Oriental of central-eastern Mexico in the states of Hidalgo, Querétaro, and Tamaulipas; expected also in adjacent San Luis Potosí. It occurs in tropical deciduous and subdeciduous forest, cloud forest, pine-oak forest, and mesic oak-Liquidamber forest at elevations from 350 to $1450 \mathrm{~m}$. Flowering begins in June with fruits maturing from September to October.

Urera martiniana is noteworthy in being monoecious and in that the inflorescences are restricted to the axils of leaves of the new growth. In these 
features it is similar to U. simplex, which occurs from Veracruz and Chiapas southward into northern South America. Urera martiniana is distinguished by its 5-merous staminate flowers that are wheel-shaped and flattened in bud and the possession of a pistillate perianth the only partially covers the ovary. In $U$. simplex the staminate flowers are 4-merous and ovoid in bud and the pistillate perianth nearcompletely covers the ovary. In addition, it appears that the staminate flowers of $U$. simplex tend to be in the distal nodes of the stems with the pistillate flowers in the lower proximal nodes, whereas in U. martiniana the opposite condition is present or the staminate flowers are few and scattered in an otherwise pistillate inflorescence. However, whether this latter difference represents a strict characterization must await further observation.

Urera martiniana is named in honor of Professor Paul S. Martin at the University of Arizona, who first introduced me to botany and the importance of floristics; he collected this species in 1958 in Tamaulipas. A photo of this species showing its monoecious nature is featured in Puig (1993) under the name Urera caracasana.

Common names: mala mujer (Rubio 243), ortiga (Rubio 243, Servín 372).

Additional specimens examined. MEXICO. Hidalgo: distr. Jacala, Puerto Obscuro, between Santa Ana and Chapulhuacán, Moore 5049 (UC). Querétaro: mpio Jalpan, al N de Carrizal, camino al Naranjo, Guzmán 100 (IEB); mpio. Landa, Aguaje del Carrizo, $5 \mathrm{~km}$ al poniente de Agua Zarca, Rubio 243 (IEB); mpio. Jalpan, 3-4 km al S de Carrizal, Ojo de Agua, Servín 372 (IEB); mpio. Jalpan, 3-4 km al $\mathrm{S}$ de La Parada, Servín 557 (IEB); mpio. Jalpan, ca. $1.3 \mathrm{~km}$ SE of La Cercada along the trail to La Mesa, ca. 2129'00" N, 9908'30" W, Steinmann \& Zamudio 2592 (ARIZ, IEB). Tamaulipas: mpio. Gómez Farías, camino a Ojo de Agua del Indio, 7 km al W de Rancho del Cielo, 18 km al W de Gómez Farías, González 4272 (MEXU); mpio. Gómez Farías, 8 km al O de El Encino, González 7353 (MEXU); Gómez Farías region, profile across the Sierra Madre Oriental, Station 6 (for exact location see map in Martin, P.S. 1958. Misc. Publ. Mus. Zoology, Univ. Mich. 101: 7), Martin \& Harrell 237 (ENCB); trail in the Cañón de Tableta and rd to Gómez Farías from Rancho Cielo, Sharp et al. xx-8204 (MEXU); mpio. Gómez Farías, Sierra de Guatemala, between Rancho del Cielo Biological Station and Old Company Clearing on rd to Julilo, Sullivan 456 (ENCB, NY).

Urera pacifica V.W. Steinm. Type: Mexico. Jalisco: along MEX 80, $12.8 \mathrm{~km}$ (by

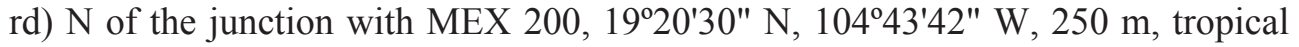
deciduous forest dominated by Acalypha, Bursera, Croton, Guazuma, Heliocarpus, and Hura, 29 VI 2003, Steinmann \& Fishbein 3265 (holotype IEB; isotypes ARIZ, MEXU). 


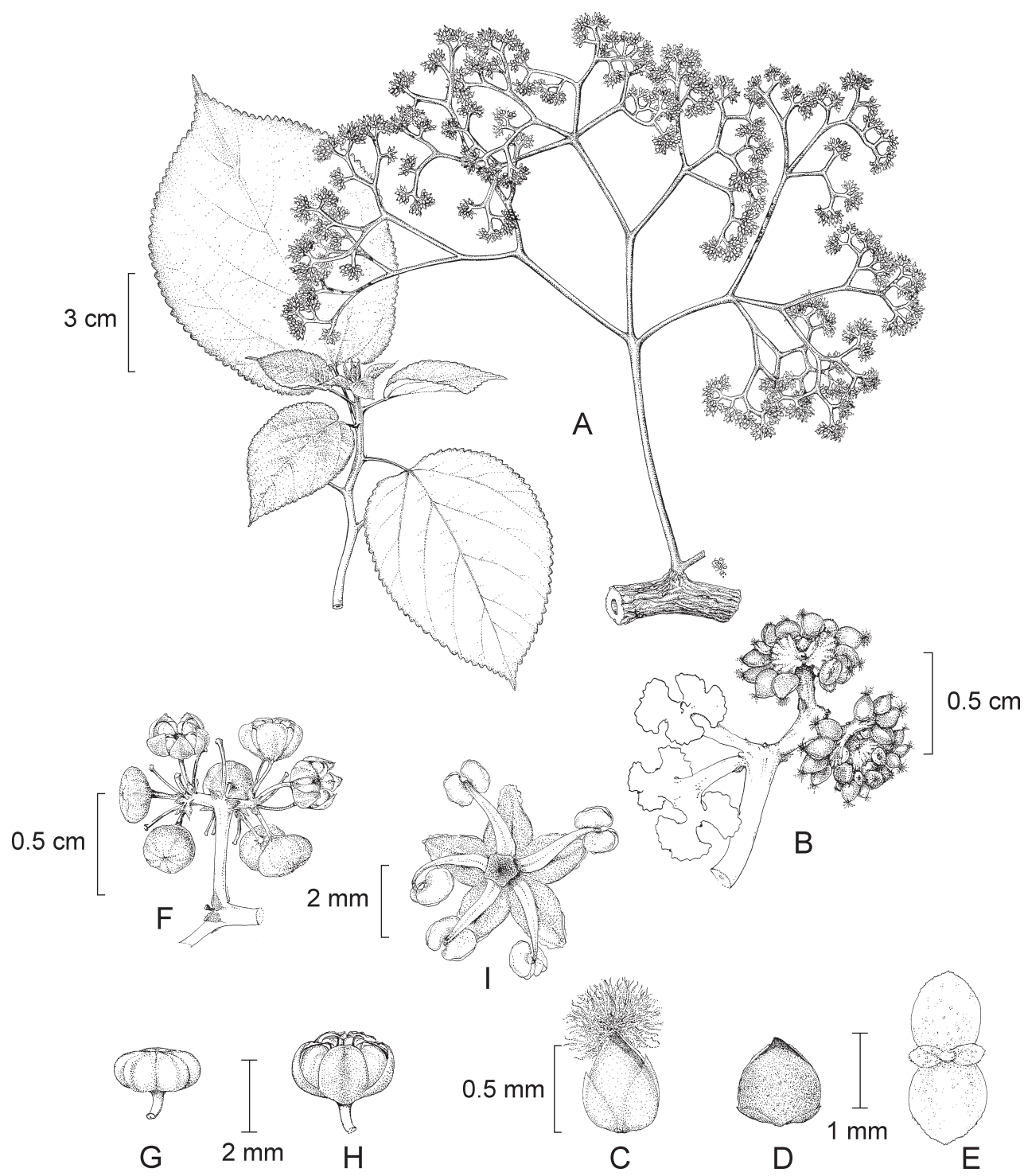

Fig. 1. Urera pacifica V.W. Steinm. A. Leafy shoot and pistillate inflorescence; B. Tip of a pistillate inflorescence showing flowers and the swollen receptacle; C. Young pistillate flower; D. Pistillate flower with accrescent tepals; E. Tepals opened; F. Tip of a staminate inflorescence; G. Staminate bud; H. Staminate bud just prior to anthesis; I. Staminate flower at anthesis. Illustrated by Karin Douthit for Flora Novo-Galiciana; copyrighted by the University of Michigan Herbarium and reproduced with permission. 
Frutex vel arbor 2-7(12) $\mathrm{m}$ alta, dioecia; stipulae anguste ovatae vel subulatae, 0.9-1.8 cm longae, apice bifido, petioli 3-5 cm longi, laminae foliorum ovatae, 11$18 \mathrm{~cm}$ longae, 6-13 cm latae, apice obtuso-acuto, basi rotundata, subtruncata, vel late cuneata, margine crenato-dentato, 3-nerviae, supra strigosae, saepe glabratae, subtus puberulae vel pilosae, saepe glabratae; inflorescentia paniculata, 4.5$22(35) \mathrm{cm}$ longa, ramosissima, unisexualis; flores staminati numerosi in fasciculis, pedicelli angusti, 0.7-3.1 mm longi, tepala 5, lobi ovati vel deltoidei, 1.4-1.8 mm longi, stamina 5, fila 1.8-2.4 mm longa, antherae 0.9-1.1 mm longae; flores pistillati in capitulis, sessiles, perianthium $0.5-1.0 \mathrm{~mm}$ longum, glabrum, ovarium tectum vel expositum, stigma penicillatum, $0.5-0.7 \mathrm{~mm}$ longum; receptaculum fructiferum carnosum, albo-translucens, achenium 1.0-1.3 mm longum.

Shrubs or small trees 2-7 $\mathrm{m}$ tall, one collection from a tree $12 \mathrm{~m}$ tall, bark often corky and highly fissured, dioecious; branchlets shortly strigose, rarely glabrescent or with urticating hairs; stipules narrowly ovate to subulate, $0.9-1.8 \mathrm{~cm}$ long, bifid at the apex, petioles 3-5 cm long, puberulent to shortly strigose, often with urticating hairs, lamina ovate, $11-18 \mathrm{~cm}$ long, $6-13 \mathrm{~cm}$ wide, apex acute with a blunt point, base rounded to almost truncate or broadly cuneate, rarely shallowly cordate, margin crenate-dentate, the teeth mostly rounded, sometime pointed, 3veined from the base, primary and secondary veins conspicuously elevated on the underside, often with urticating hairs, upper surface strigose, often glabrescent, lower surface puberulent to shortly pilose, often glabrescent, cystoliths of the upper surface punctiform, essentially evenly arranged over the surface, cystoliths of the lower surface slightly elongated, arranged in a reticulate pattern above the veins; inflorescences much-branched panicles, mostly arising from the woody stem below new growth, unisexual, the staminate $4.5-12 \mathrm{~cm}$ long, the pistillate $10-22(35) \mathrm{cm}$ long, relatively loose and open with well-spaced internodes, primary peduncle 1.5$9 \mathrm{~cm}$ long, rachis puberulent and with urticating hairs; staminate flowers numerous in dense fascicles at the ultimate tips of the inflorescence branches, pedicel slender, 0.7-3.1 mm long, bud wheel-shaped and flattened, tepals 5, outer surface puberulent to sparsely strigose, lobes ovate to deltoid, $1.4-1.8 \mathrm{~mm}$ long, stamens 5, filaments 1.8-2.4 mm long, anthers 0.9-1.1 mm long; pistillate flowers numerous in dense, headlike clusters at the ultimate tips of the inflorescence branches, sessile, perianth $0.5-1.0 \mathrm{~mm}$ long, glabrous, almost completely covering the achene or rarely with the upper portion of the achene exposed, stigma penicillate, 0.5 $0.7 \mathrm{~mm}$ long; fruits with the receptacle instead of the perianth becoming fleshy, white-translucent, achene strongly flattened, ovoid in outline, 1.0-1.3 $\mathrm{mm}$ long, pointed and sometime curved at the apex.

Endemic to Mexico where it occurs along the Pacific slope from Sinaloa to Oaxaca and in the Balsas Depression in Michoacán, Edo. de México, and Guerrero. 
It prospers in tropical deciduous forest, with a few collections from cloud forest and humid pine-oak forest; 80-1600(2400) $\mathrm{m}$. Flowering begins in early May, with fruits maturing from late June to August.

Urera pacifica is unique among the Mexican species of Urera in that during fruiting the tips of the inflorescence become fleshy instead of the perianth. It shares this feature with U. caracasana, and the two are probably closely related. Urera pacifica differs from $U$. caracasana by the possession of 5-merous staminate flowers. Also, characteristics of the achenes serve to distinguish them: in U. pacifica the achenes are larger (1.0-1.3 mm long vs. 0.7-1.0 mm long), ovate in outline (vs. suborbicular), and usually enveloped almost entirely by the perianth (vs. exposed in the upper half).

Common names: chichicaste (Chiang et al. 720), mala mujer (Howell 10441), ortiga (Soto \& Ramos 680), ortiga blanca (Blanco et al. 1005), ortigo (Hinton et al. 10225, Rendón 402), ortigo blanco (Hinton et al. 10235), ortigo colorado (Hinton et al. 10274), quemador (Hernández-Galaviz \& Ordorika 32), quemadora (Castillo et al. 5288).

Additional specimens examined. MEXICO. Colima: mpio. Minatitlán, 8-9 km al ENE de Minatitlán, 1-2 km NW de Platanarillos, 19²4'42" N, 1035' $14^{\prime \prime}$ W, Cuevas \& Guzmán 4008 (ZEA). Edo. de México: distr. Temascaltepec, Luvianos, Hinton 3737 (K). Guerrero: mpio. Chilpancingo, $74 \mathrm{~km}$ al S de Cd. Altamirano, por la carr. a Zihuatanejo, Blanco et al. 1005 (XAL), ibid., Blanco et al. 1008 (XAL); Puerto Marqués, Chiang et al. 720 (MEXU); distr. Montes de Oca, Vallecitos, Hinton et al. 10225 (K), ibid., Hinton et al. 10235 (ENCB, K, NY, RSA), ibid., Hinton et al. 10274 (K, NY, RSA); distr. Mina, Palma, Hinton et al. 10115 (ENCB, K, NY, RSA); mpio. Acapulco, $2.5 \mathrm{~km} \mathrm{~W}$ de Puerto Marqués, López 886 (MEXU); mpio. La Unión, $18 \mathrm{~km}$ al NE de El Bálsamo, Ramamoorthy 4296 (MEXU); cerro al E de Tierra Colorada, Rzedowski 22804 (DS, ENCB); mpio. Zirándaro, $6 \mathrm{~km}$ al E de Guayameo, Soto \& Ramos 680 (MEXU). Jalisco: vic. of Chamela and Cuitzmala, Arroyo Careyes, a few mi N of Rancho Cuitzmala on Puerto Vallarta-Barra de Navidad Hwy. (MEX 200), near $19^{\circ} 27^{\prime} \mathrm{N}, 105^{\circ} 02^{\prime} \mathrm{W}$, Ayala 106 (UCR), ibid., Ayala 194 (UCR); Chamela, Estación de Biología, Bullock 1749 (CAS, IEB), ibid., Bullock 1750 (IEB); mpio. San Cristóbal de la Barranca, Arroyo Los Cuartos (El Escalón), $2 \mathrm{~km}$ al O de La Arena por el camino a Los Pueblitos, 20 $0^{\circ} 9^{\prime} \mathrm{N}, 1^{\circ}{ }^{\circ} 25^{\prime} \mathrm{W}$, Carrillo et al. 1203 (IEB); mpio. La Huerta, Cuitzmala, en el Cerro de Alborada, 19²4'20" N, 104'59'25" W, Castillo et al. 5288 (UCR, XAL); mpio. Casimiro Castillo, 7-8 km al NNE de Casimiro Castillo, Arroyo La Calera, 1940'16" N, 104²5'04" W, Cuevas \& Núñez 3074 (ZEA); mpio. Autlán, La Calera, Cuevas \& Rosales $2178 a$ (ZEA); mpio. Hostotipaquillo, Puente Barranquitas, por la ribera del arroyo, Flores \& Guzmán 364 (IBUG); mpio. 
Zapotitlán, $82 \mathrm{~km}$ de Cd. Guzmán, carr. a San Antonio, Colima (pasando por Queseria) y $14 \mathrm{~km}$ de San Antonio, brecha a Las Moras, Gaona 414 (IEB); mpio. Guadalajara, Barranca Huentitán-Oblatos, Hernández-Galaviz \& Ordorika 32 (IBUG, IEB, NY); hillside above km post 16 on highway $41 \mathrm{~N}$ of Guadalajara, $L a$ Follette 417 (RSA); mpio. Autlán, $6 \mathrm{~km}$ al W de Autlán, luego $1 \mathrm{~km}$ al pied., Rancho Chiquihuitlán, Lott 441 (IBUG, IEB, MEXU), ibid., Lott 3701 (UCR); mpio. Villa Corona, camino al NE de Atotonilco el Bajo, rumbo al Cerro de la Tortuga, Machuca 5962 (IBUG); mpio. Zapotitlán, $11 \mathrm{~km}$ sobre la desv. al Nevado de Colima, Parque del Volcán de Colima, Mtz. 69 (IEB, MEXU); mpio. Tuxcacuesco, $1 \mathrm{~km}$ al O de Zenzontla, 19³9' N, 104 $05^{\prime} \mathrm{W}$, Robles 645 (ZEA); mpio. Hostotipaquillo, La Venta de Mochitiltic, Rodríquez \& Suárez 883 (ENCB, IBUG); mpio. La Huerta, La Concha, 4 VII 1999, Rosales et al. s. n. (IBUG). Michoacán: mpio. Coahuayana, carr. Manzanillo-Lázaro Cárdenas, El Ojo de Agua de San Telmo, Soto \& Cortés 2589 (MEXU); mpio. Chinicuila, 11 km al SO de Villa Victoria, Soto Núñez 9470 (MEXU); mpio. Arteaga, along MEX 37, ca. $2.5 \mathrm{~km}$ (by rd) S of El Zorrillo, $18^{\circ} 16^{\prime} 20^{\prime \prime} \mathrm{N}, 102^{\circ} 16^{\prime} 30^{\prime \prime} \mathrm{W}$, Steinmann 2444 (IEB); mpio. Múgica, along the Morelia-Lázaro Cárdenas autopista, $2 \mathrm{~km} \mathrm{NE}$ of the exit for Nueva Italia, old lava flow east of the highway, $19^{\circ} 00^{\prime} 15^{\prime \prime} \mathrm{N}, 102^{\circ} 04^{\prime} 30^{\prime \prime} \mathrm{W}$, Steinmann 3386 (ARIZ, IEB), ibid., Steinmann \& Fishbein 3230 (ARIZ, IEB); mpio. Aguililla, $7.3 \mathrm{~km}$ (by rd.) WSW of La Paz (at the junc. with Aguililla-Apatzingán rd.) along the rd. to Dos Aguas, 18²4'19" N, 102 48'35" W, Steinmann \& Fishbein 3243 (ARIZ, IEB). Nayarit: mpio. Nayar, Arroyo de los Bueyes, Benitez-Paredes 3176 (MEXU); mpio. Nayar, Arroyo Brasil, Embalse P.H. Aguamilpa, aprox. $10 \mathrm{~km}$ al E de la

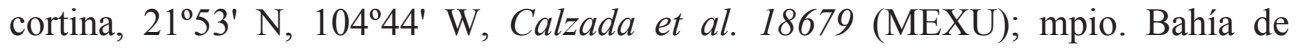
Banderas, $5 \mathrm{~km}$ adelante de Higuera Blanca hacia carr. federal, $20^{\circ} 47^{\prime} 00^{\prime \prime} \mathrm{N}$, 105²9'00" W, Castillo et al. 5695 (XAL); mpio. Bahía de Banderas, Brasil, 20 $47^{\prime} 00^{\prime \prime} \mathrm{N}, 105^{\circ} 18^{\prime} 00^{\prime \prime} \mathrm{W}$, Castillo et al. 5745 (XAL); Tres Marías Islands, María Madre, Howell 10441 (CAS); km 5-10 del camino a Cacalotán, 2109' N, 104¹6' W, Téllez 10633 (MEXU). Oaxaca: distr. Tuxtepec, mpio. Soyaltepec, Presa Temascal, lado E de Isla Isabel María, Cortés 949 (MEXU); distr. Pochutla, mpio. Santa María Huatulco, La Javalina, $500 \mathrm{~m}$ al N de Puente Tangolunda, 15²7'41.6" N, 9606'43.4" W, Elorsa 6956 (MEXU); distr. Putla, mpio. Santa María Zacatepec, $1 \mathrm{~km}$ al SSE de Nejapa, López 607 (MEXU); distr. Pochutla, mpio. San Miguel del Puerto, $5 \mathrm{~km}$ al $\mathrm{N}$ del Pueblo de Zimatán y aprox. $2 \mathrm{~km}$ al E del Río Zimatán, 1552'06" N, 9600'06" W, Reyes-García 3482 (MEXU); distr. Tehuantepec, $14 \mathrm{~km}$ al NW de Tehuantepec, ladera S del Cerro Guiengola, entrando por Paso Alicia, Torres 425 (IEB, MEXU, XAL); distr. Jamiltepec, $5 \mathrm{~km}$ al $\mathrm{N}$ de la entrada a Vivero Guapinol hacia San Agustín Chayuco, Torres 621 (MEXU); 2 km al NW de La Catalina ó $18 \mathrm{~km}$ al NW de Pinotepa, Torres 5474 (MEXU); distr. Tehuantepec, Arroyo de las Minas, al W de El Limón, entrando por la desv. a Buenos 
Aires, Torres 6845 (IBUG, IEB, MEXU); distr. Juquila, mpio. San Pedro Mixtepec, El Puente de San José, $8 \mathrm{~km}$ al N de Puerto Escondido, hacia Oaxaca, Torres 8437 (MEXU). Sinaloa: $5 \mathrm{mi} \mathrm{W}$ of Concordia, Breedlove 36424 (CAS); mpio. Concordia, Coapla, $10 \mathrm{~km}$ al N de Concordia, Hernández 7396 (MEXU); Cerro El Elefante, $17.85 \mathrm{mi}$ E of MEX 15 and $5 \mathrm{mi} \mathrm{E}$ of Concordia, near $23^{\circ} 18^{\prime} \mathrm{N}, 106^{\circ} 00^{\prime} \mathrm{W}$, Sanders 8054 (RSA, UCR); mpio. Culiacán, $\pm 2-4 \mathrm{~km}$ al E de Tacuichamona, Valverde 93 (MEXU); mpio. Cosalá, Guadalupe de los Reyes, Vega 1914 (MEXU).

Urera rzedowskii V.W. Steinm. Type: Mexico. Veracruz: mpio. San Andrés Tuxtla, $8 \mathrm{~km}$ al N de San Andrés Tuxtla, Laguna Encantada, 18²8' N, 95 $10^{\circ} \mathrm{W}$, $350 \mathrm{~m}$, selva alta subperennifolia, cálido húmedo, primaria, suelo negro arenoso pedregoso, 04 IX 1981, Calzada 8105 (holotype IEB; isotype ENCB).

Frutex vel arbor 2-13 m alta, dioecia; stipulae subulatae 0.9-1.6 cm longae, apice bifido, petioli 5-12 cm longi, laminae foliorum ellipticae vel ovatae, $10-27 \mathrm{~cm}$ longae, $5-13 \mathrm{~cm}$ latae, apice acuto vel acuminato, basi rotundata vel cuneata, raro minute cordata, margine dentato-crenato, 3-nerviae, supra parce strigosae, subtus piloso-strigosae; inflorescentia paniculata, $2.5-5 \mathrm{~cm}$ longa, ramosissima, unisexualis; flores staminati pauci vel numerosi in fasciculis, pedicelli angusti, $0.6-2.9 \mathrm{~mm}$ longi, tepala 5, lobi ovati vel deltoidei, 0.9-1.4 mm longi, stamina 5, fila 1.3-1.7 mm longa, antherae $0.6-0.8 \mathrm{~mm}$ longae; flores pistillati in fasciculis, subsessiles vel pedicelli ad $0.2 \mathrm{~mm}$ longi, perianthium $0.9-1.1 \mathrm{~mm}$ longum, glabrum, ovarium tectum, stigma penicillatum, 0.2-0.3 mm longum; perianthium fructiferum carnosum, 1.4-1.7 mm longum, aurantiacum vel rubrum, achenium ca. $1 \mathrm{~mm}$ longum.

Shrubs or trees 2-13 m tall, dioecious; branchlets strigose to almost pilose, sometimes with a lower puberulent layer also present; stipules narrowly ovate, 0.9$1.6 \mathrm{~cm}$ long, bifid at the apex, petioles slender, $5-12 \mathrm{~cm}$ long, strigose to pilose, hairs characteristically long, slightly curved and spreading, rarely almost appressed, lamina elliptic to ovate, $10-27 \mathrm{~cm}$ long, $5-13 \mathrm{~cm}$ wide, apex acute to acuminate, base rounded to cuneate or rarely shallowly cordate, margin dentate-crenate, teeth acute at least when young, 3-veined from the base, primary and secondary veins conspicuously elevated on the underside, distance between the basal and second pairs of veins essentially equal to the distance between the second and third pairs of veins, upper surface sparsely strigose, lower surface pilose-strigose, cystoliths of the upper leaf surface characteristically elongate and having the appearance of radiating from the trichomes, cystoliths of the lower leaf surface generally elongated and distributed primarily in a reticulate network above the veins; inflorescences in the axils of new growth or arising from the woody stem below the new growth, unisexual, muchbranched panicles $2.5-5 \mathrm{~cm}$ long, primary peduncle $1-1.5 \mathrm{~cm}$ long, rachis puberulent 


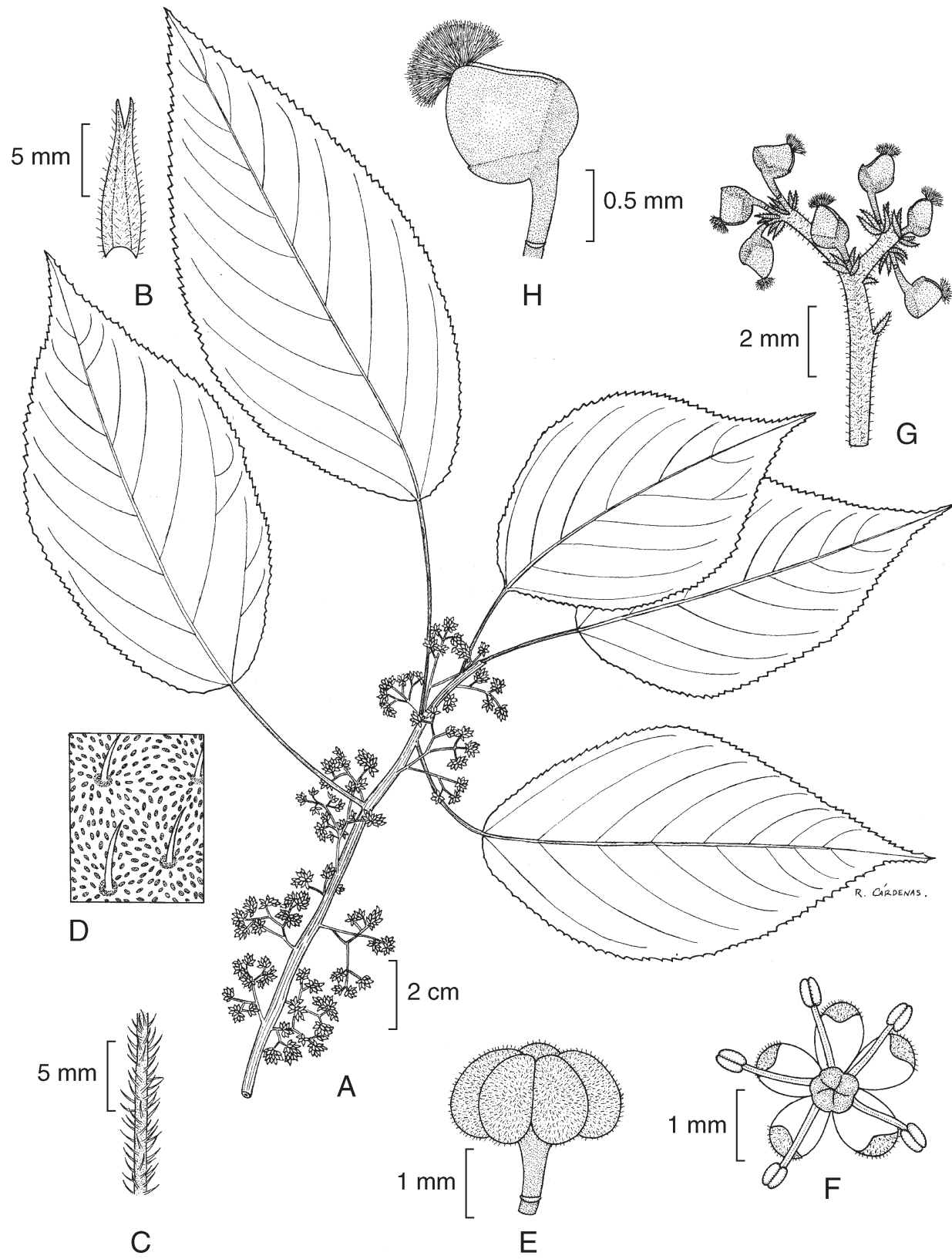

Fig. 2. Urera rzedowskii V.W. Steinm. A. Branch with pistillate flowers; B. Stipule; C. Portion of a petiole; D. Close-up of upper surface of a leaf showing cystoliths arranged in radiating patterns; E. Staminate bud; F. Staminate flowers at anthesis; G. Tip of a pistillate inflorescence; H. Pistillate flower with accrescent tepals. Illustrated by Rogelio Cárdenas. 
to pilose, urticating hairs generally lacking; staminate flowers in few-flowered fascicles or in dense headlike clusters at the tips of the inflorescence branches, pedicel slender, 0.6-2.9 $\mathrm{mm}$ long, bud wheel-shaped and flattened, tepals 5, lobes deltoid to ovate, outer surface glabrous to puberulent, 0.9-1.4 $\mathrm{mm}$ long, rounded at the apex, stamens 5, filaments 1.3-1.7 $\mathrm{mm}$ long, anthers 0.6-0.8 $\mathrm{mm}$ long; pistillate flowers in few-flowered clusters at the ultimate tips of the inflorescence, subsessile or on pedicels to $0.2 \mathrm{~mm}$ long, bent away from the pedicels, perianth 0.9-1.1 mm long, glabrous, completely covering the achene, stigma penicillate, $0.2-$ $0.3 \mathrm{~mm}$ long; fruits with the perianth becoming fleshy, 1.4-1.7 $\mathrm{mm}$ long, orange to red, achenes lenticular, nearly orbicular in outline, ca. $1 \mathrm{~mm}$ long, with a small point at the apex.

Urera rzedowskii is one of the most common species of Urera in Mexico and Central America. It occurs from east-central Mexico south to Columbia, growing in perennial or subdeciduous tropical forest and cloud forest at elevations from near sea level to $1650 \mathrm{~m}$.

This species corresponds to Urera alceifolia Gaud., sensu Standley and Steyermark (1952), and is frequently found identified as such in herbaria. However, an examination of type material of $U$. alceifolia at P (French Guiana, Martin s. n., various syntypes!) demonstrates that $U$. alceifolia is in fact synonymous with $U$. caracasana, as Berg (1992) and Killip (1960) have previously reported. Despite being a common and widespread species, I can find no other name for it. Based on an examination of specimens annotated by the following authors, as well as their descriptions, this entity also corresponds, at least in part, to Burger's concept of $U$. elata (1977) and Pool's use of U. eggersii (2001).

However, in both instances I believe these represent misapplications. Urera rzedowskii is distinctive and separable from these species by the combination of a shrubby or arborescent habit; petioles that are often densely pubescent with long, spreading hairs; an upper leaf surface possessing elongated cystoliths that are arranged in a pattern as if they are radiating from the trichomes; consistently 5merous staminate flowers; and pistillate flowers the are bent away in relation to the pedicel.

The specific epithet is in honor of Dr. Jerzy Rzedowski, without whose encouragement this article would not have been possible. He made various collections of this species, the first in 1966.

Common names: chichicastle (González \& Garza 2079), chichicastillo (González \& Garza s. n., González \& Garza 3012), kokotzte (Rzedowski 9953), pica pica (Gentle 7356), poison ivy (Gentle 6263, 7356), cow itch (Gentle 6263, 7356), pochalanti (Rzedowski 10994), hueva de cangreja (Soto \& Horvitz 43), 
hueva de cangrejo (Ibarra 394, 1736, 2488, Torquebiau 1028), mal hombre (Avendaño et al. 32).

Additional specimens examined. BELIZE. Cayo: along Sibum River near crossing of Hummingbird Highway, Gentry 8427 (MEXU); Chiquibul Forest

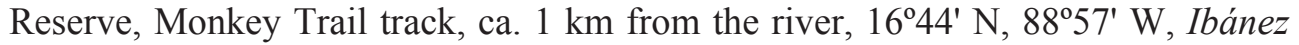
A30 (BM, MEXU). Toledo: along trail to Esperanza beginning $1 \mathrm{mi} \mathrm{N}$ of Columbia Forest Station, Croat 24254 (POM); Columbia Forest Station, Dwyer 9835 (CAS, MEXU); Chavarrias Rd., Resemederes, across Columbia River, Gentle 6263 (CAS, MEXU, NY, UCR); hillside beyond Central Camp, Edwards Road beyond Columbia, Gentle 7356 (CAS, MEXU); Jimmy Cut, Salamanca, Whitefoord 1881 (BM); Columbia Forest Reserve, Whitefoord 3248 (BM, MEXU), ibid., Whitefoord 3250 (BM, MEXU). Stann Creek: Middlesex, Schipp 400 (BM, K, UC). COLOMBIA. Antioquia: mpio. Segovia, $11.5 \mathrm{~km} \mathrm{~N}$ of La Cruzada $(19 \mathrm{~km} \mathrm{~N}$ of Remedio) on rd to Zaragoza, $07^{\circ} 08^{\prime} \mathrm{N}, 7^{\circ} 45^{\prime} \mathrm{W}$, Thomas \& Castaño 5492 (NY). COSTA RICA. Limón: Río Sixaola drainage, 1-3 km N of Bribri, 09 $38^{\prime} \mathrm{N}, 82^{\circ} 40^{\prime}$ W, Burger \& Antonio 10956 (MEXU). Puntarenas: Cordillera de Talamanca, area around Río Canasta, 9.5 airline km NW of Agua Caliente, between Cerro Frantzius and Cerro Pittier, 09 $02^{\prime}$ N, 82 $2^{\circ} 59^{\prime}$ W, Davidse et al. 28441 (MEXU); Monte Verde area, valley of Río San Luis just $\mathrm{S}$ of Monte Verde, from $1 / 2 \mathrm{~km}$ below waterfall to base of waterfall, $10^{\circ} 16^{\prime} \mathrm{N}, 84^{\circ} 48^{\prime} \mathrm{W}$, Hammel \& Trainer 14009 (MEXU). EL SALVADOR. Ahuachapán: mpio. Ahuachapán, alrededores del Salto de Atehuecía, Linares 3288 (MEXU). GUATEMALA. Izabal: Livingston, San Juan Pacayal, Véliz 98.6827 (MEXU). Petén: Dolores, Río Mopan, about $4 \mathrm{~km}$ E of the village, Contreras 2264 (CAS, MEXU, NY, UCR); Chinchila, on Sebol Road, 8 km from San Luis, Contreras 6362 (CAS, MEXU, NY). HONDURAS. Atlántida: en el Jardin Botánico de Lancetilla, a $3 \mathrm{~km}$ al N de Tela, Martínez 12839 (BM, ENCB, MEXU); Lancetilla, $5 \mathrm{~km}$ SO de Tela, Martínez 31 (BM); near Lancetilla, bank of Tela River, Yuncker 4514 (NY); foothills back of La Ceiba, Yuncker et al. 8025 (NY); vic. of La Ceiba, slopes of Mt. Cangrejal, near Danto River, Yuncker et al. 8481 (NY). Olancho: mpio. La Unión, Los Planes de Sirei, a 6 km de La Montaña La Muralla, Araque 1008 (MEXU); Catacamas, Río Catacamas, slope of Sierra de Agalto, Blackmore \& Heath 1916 (MEXU). MEXICO. Chiapas: mpio. Berriozábal, $13 \mathrm{~km}$ N of Berriozábal near Pozo Turipache and Finca El Suspiro, Breedlove 20207 (DS, ENCB, RSA); mpio. Villa Corzo, Cerro Bola, along a logging rd SW of Colonia Agronomos Mexicanos, Breedlove 24109 (DS, MEXU); mpio. Pichucalco, $10 \mathrm{~km}$ NE of Pichucalco, Breedlove 35051 (MEXU); mpio. Berriozábal, $13 \mathrm{~km} \mathrm{~N}$ of Berriozábal, near Pozo Turipache and Finca El Suspiro, Breedlove 35424 (DS, MEXU); mpio. Ocozocuautla, $32 \mathrm{~km} \mathrm{~N}$ of Ocozocuautla on rd to Mal Paso, Breedlove 38243 (DS, MEXU); $46 \mathrm{~km} \mathrm{~N}$ of Ocozocuautla on rd to Mal Paso, Breedlove 38679 (DS, MEXU); mpio. Villa Corzo, E base of Cerro Tres Picos 
near Cerro Bola, along a logging rd SW of Colonia Agronomos Mexicanos, Breedlove \& Thorne 30210 (DS, MEXU); mpio. Ocosingo, alrededor del nuevo centro de población Velasco Suárez, Calzada et al. 2804 (ENCB, MEXU, XAL); mpio. Ocosingo, Estación Biológica Chajul, dentro de la reserva, $16^{\circ} 07^{\prime} \mathrm{N}, 90^{\circ} 55^{\prime} \mathrm{W}$, Domínguez 533 (MEXU, XAL); mpio. Ocozocuautla, $20 \mathrm{~km}$ sobre la desviación a Apitpac, Espejo 2105 (ENCB, MEXU); mpio. Ocozocuautla, 24 km al NNW de Ocozocuautla, sobre el camino a la Presa Malpaso, Koch 77266 (ENCB); mpio. Ocozocuautla, km 4.9 de Malpaso, km 90 de Huimanguillo hacia Malpaso, Cowan 3064 (CAS, ENCB); $3 \mathrm{~km} \mathrm{NE}$ of Pichucalco on rd to Villahermosa, along the Río Pichucalco, $17^{\circ} 32^{\prime} \mathrm{N}, 93^{\circ} 04^{\prime} \mathrm{W}$, Marcks \& Marcks 896 (ENCB); ca. $1 \mathrm{~km} \mathrm{~S}$ of San Miguel on gravel rd from Palenque, McPherson 754 (CAS, ENCB); mpio. Ocozocuautla, E $500 \mathrm{~m}$ del Cerro El Perico, Cañada La Palma, 1701'30" N, 9346'45" W, Ochoa-Gaona 3772 (XAL); 8 km al S de Ixtacomitán en La Lupita, Téllez 7821 (IEB, XAL); 10-13 km al N de Berriozábal entre El Suspiro y el pozo petrolero Turipache, Téllez \& Pankurst 7277 (BM, CAS, MEXU); mpio. Ocozocuautla, camino Ciprés a Horizonte, Vázquez 987 (XAL); mpio. Tapachula, Cantón El Chaparrón, Ventura \& López 1556 (ENCB, MEXU, XAL); mpio. Cacahoatán, Unión Roja, Ventura \& López 2376 (ENCB, MEXU, XAL); mpio. Cacahoatán, Aguacatlán, Ventura \& López 3629 (ENCB, IEB, MEXU, XAL). Hidalgo: mpio. Tenango de Doria, Santa María, $22 \mathrm{~km}$ al E de Tenango de Doria, Hernández 5519 (CAS, ENCB, MEXU). Oaxaca: distr. Tuxtepec, Presa Temazcal, Cortés 116 (MEXU); distr. Tuxtepec, mpio. Acatlán, Cerro del Tigre, $3 \mathrm{~km}$ al E de Acatlán, Cortés 472 (CAS, MEXU); distr. Juchitán, mpio. Santa María Chimalapa, San Antonio Nuevo Paraíso, a $500 \mathrm{~m}$ en línea recta al W, en el Cerro Mono, 1709'34" N, 94²1'33" W, García 625 (MEXU); distr. Ixtlán, mpio. Santiago

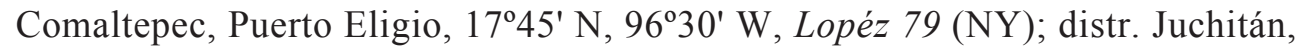
mpio. Matías Romero, Los Ángeles, $20 \mathrm{~km}$ al NO del entronque con la carr. Matías Romero-Acayucan, la entrada se encuentra adelante de Martín Dehesa, $17^{\circ} 22^{\prime} 00^{\prime \prime}$ N, 95 $08^{\prime} 00^{\prime \prime} \mathrm{W}$, Martinez 1079 (RSA); distr. Tuxtepec, Chitepec and vic., Martínez-Calderón 480 (UC); 8.5 mi NE of Valle Nacional, Thurm et al. 233 (MEXU). Puebla: $35 \mathrm{~km}$ al NE de Villa Juárez, El Salto, Germán \& Pinzón 1000 (MEXU); Mpio. Jonotla, Barranca del Río Tozan, Meza 213 (XAL); Jonotla, Barranca del Río Tozan, Meza 249 (XAL); mpio. Metlaltoyuca, Tecomate, $20^{\circ} 40^{\prime} \mathrm{N}, 9^{\circ} 55^{\prime} \mathrm{W}$, Vargas 162 (XAL). Querétaro: mpio. Landa, $8 \mathrm{~km}$ al NE de El Humo, sobre el camino a Neblinas, Zamudio 7308 (IEB); mpio. Landa, $10 \mathrm{~km}$ al SE de Agua Zarca, sobre el camino a Pisaflores, Rzedowski 43360 (ENCB, IEB, MEXU, XAL); mpio. Landa, $4 \mathrm{~km}$ from Neblinas along the rd to El Humo, $21^{\circ} 15^{\prime} 34^{\prime \prime}$ N, 99 $04^{\prime} 48^{\prime \prime}$ W, Steinmann et al. 2558 (IEB), ibid., Steinmann \& Zamudio 2814 (IEB). San Luis Potosí: mpio. Aquismón, Mante Tsulel, Alcorn 3073 (MEXU); Huichihuayán, Cruz 1456 (ENCB); ca. 9 mi NE of Xilitla, King 
4417 (NY, UC); \pm 2 km al SW de Aquismón, Rzedowski 9953 (ENCB); alrededores de Tamán, municipio de Tamazunchale, Rzedowski 10994 (ENCB). Tabasco: municipio de Tacotalpa, cerro arriba del Ejido Zunú, en el camino de la Est. Tacotalpa hacia Tapijulapa, Cowan 3109 (CAS, ENCB); mpio. Teapa, a $2 \mathrm{~km}$ de Teapa, Cowan 3151 (CAS, ENCB, MEXU); mpio. Teapa, arriba del cerro en Puyacatengo por el campo experimental de Chapingo, Magaña 1559 (ENCB, MEXU, XAL); mpio. Teapa, Cerro Coconá, Gruta del Coconá, cerca de Teapa, Ramos \& Cowan 2685 (CAS or DS, ENCB, MEXU); mpio. Teapa, El Azufre, Ventura 21062 (ENCB, MEXU). Veracruz: mpio. Atoyac, Ejido La Esperanza, 1852' N, 96 $44^{\prime}$ W, Acevedo \& Castillo 267 (XAL); Tonayan, Congregación Iztapan, Avendaño et al. 32 (ENCB); mpio. San Andrés Tuxtla, Estación de Biología Tropical Los Tuxtlas, 18³5' N, 95 $05^{\prime} \mathrm{W}$, Calzada 1351 (MEXU); mpio. San Andrés Tuxtla, Estación de Biología Tropical Los Tuxtlas, 18³6' N, 9505' W, Calzada 7836 (ENCB, MEXU); mpio. San Andrés Tuxtla, $8 \mathrm{~km}$ al N de San Andrés Tuxtla, Laguna Encantada, 18²8' N, 95¹0' W, Calzada 8105 (ENCB, IEB, MEXU); mpio. San Andrés Tuxtla, Volcán de San Martín Tuxtla lado S, camino para el cráter lado S, Calzada 10614 (IEB, MEXU, XAL); mpio. San Andrés Tuxtla, a 5 km al NE de San Andrés Tuxtla por la antigua carr. a Mastagaga, Laguna Encantada, $18^{\circ} 28^{\prime} \mathrm{N}$, 9510' W, Calzada 10726 (IEB, MEXU); mpio. Catemaco, Dos Amates, al S, en La Cascada Encantada, Calzada 11693 (IEB, MEXU, XAL); mpio. Catemaco, al N de Catemaco, Cerro Nopo, Calzada 11773 (IEB, MEXU, XAL); mpio. San Andrés Tuxtla, Sierra de los Tuxtlas, al N de San Andrés Tuxtla, senda para Cerro Baxin, Calzada 11914 (IEB, MEXU, XAL); mpio. Vega de Alatorre, El Centenario, a 20 $\mathrm{km}$ al NE de Santa Gertrudis, Castillo \& Benavides 2018 (ENCB, MEXU); 4 km al $\mathrm{N}$ de Catemaco, desv. a Coyame, lado $\mathrm{N}$ de la Laguna de Catemaco, Cedillo 2469 (IEB, MEXU); mpio. Catemaco, $4.5 \mathrm{~km} \mathrm{~W}$ of Sontecomapan on rd to Catemaco, Cowan 5788 (CAS, NY); mpio. Hidalgotitlán, km 1-6 del camino Cedillo-La Laguna, Dorantes 3189 (MEXU, XAL); Hidalgotitlán, km 8 del camino Cedillo-La Laguna, $17^{\circ} 00^{\prime} \mathrm{N}, 94^{\circ} 35^{\prime} \mathrm{W}$, Dorantes et al. 3726 (CAS, ENCB, MEXU); mpio. Tenochtitlan, El Mirador, García-Orta \& Vázquez 68 (XAL); $6.5 \mathrm{~km}$ de Santiago Tuxtla, $1.5 \mathrm{~km}$ al Cerro del Mirador, 21 VII 1960, González \& Garza s. $n$. (MEXU); km 7 carr. Coyame-Catemaco, González \& Garza 2079 (MEXU); "Basuras" km 18 Catemaco-Las Palmas, González \& Garza 3012 (MEXU); mpio. Vega de Alatorre, $1 \mathrm{~km}$ camino Vista Alegre-El Centenario, Guerrero \& Calzada 1813 (IEB, MEXU, XAL); Misantla, VI 1866, Hahn s. n. (P); mpio. San Andrés Tuxtla, Estación de Biología Tropical Los Tuxtlas, lote 67, Ibarra 394 (MEXU), ibid., Ibarra 639 (ENCB, MEXU, XAL), ibid., Ibarra 1152 (ENCB, MEXU, XAL), ibid., Ibarra 1736 (ARIZ, ENCB, MEXU, XAL), ibid., Ibarra 1747 (ENCB, MEXU, NY, XAL); mpio. San Andrés Tuxtla, Estación de Biología Tropical Los Tuxtlas, límite norte, Ibarra 2488 (MEXU, XAL); mpio. San Andrés Tuxtla, Estación Biología San 
Andrés Tuxtla, Martínez 1905 (BM, CAS, ENCB, IBUG, K, MEXU, NY); mpio. San Andrés Tuxtla, Estación Biológica de los Tuxtlas, Martínez 2116 (MEXU, NY, XAL); mpio. Puente Nacional, Barranca de Palmillas, $2 \mathrm{~km}$ al SE de dicha población, Medina \& Vázquez 622 (MEXU, XAL); mpio. Coxquihui, camino a La Higuera saliendo de Coxquihui, Meza 171 (XAL); mpio. Totutla, $1.8 \mathrm{~km} \mathrm{SSE}$ of El Mirador and turnoff from the Totutla-Conejos highway, $19^{\circ} 12^{\prime} \mathrm{N}, 96^{\circ} 51^{\prime} \mathrm{W}$, Nee \& Cortez 23372 (XAL); vic. Cerro del Águila, $13 \mathrm{~km} \mathrm{~N}$ of Altotonga (19 km by rd), on rd to Tlapacoyan, $19^{\circ} 53^{\prime} \mathrm{N}, 9^{\circ} 13^{\prime} \mathrm{W}$, Nee \& Hansen 18541 (MEXU, XAL); mpio. Totutla, camino en la barranca de El Mirador, Pankhurst 85117 (MEXU, $\mathrm{XAL}$ ); mpio. Catemaco, on Catemaco-Montepio rd, $0.3 \mathrm{~km} \mathrm{NW}$ of turnoff to Playa Escondida, Perino 3103 (ENCB, MEXU, NY); Misantla, Purpus 5969 (NY, UC); mpio. Tezonapa, Sierra Cruz Tetela, $5 \mathrm{~km}$ al SE de Motzorongo, 18 $8^{\circ} 40^{\prime} \mathrm{N}, 96^{\circ} 40^{\prime} \mathrm{W}$, Robles 150 (XAL); mpio. Tezonapa, $5 \mathrm{~km}$ al NO de Motzorongo, $18^{\circ} 40^{\prime} \mathrm{N}$, 96 40' W, Robles 281 (XAL); mpio. Tezonapa, Sierra Cruz Tetela, 4 km al SE de Motzorongo, 18 $40^{\prime} \mathrm{N}, 96^{\circ} 40^{\prime} \mathrm{W}$, Robles 866 (XAL); Alta Luz, cerca del Vijía de Santiago, Sousa 2591 (ENCB, MEXU); La Estación de Biología de los Tuxtlas, Soto \& Horvitz 43 (CAS, MEXU, NY), ibid., Torquebiau 1028 (MEXU); mpio. Tlapacoyan, El Arco, Ventura 1102 (DS, ENCB, NY); mpio. Tlapacoyan, El Paraíso, Ventura 12341 (ENCB, MEXU, NY); mpio. Catemaco, Arroyo Agrio, Ventura 12784 (ENCB, MEXU, NY); mpio. Santiago Tuxtla, Loma Quemada, Ventura 14023 (ENCB, MEXU, NY, XAL); mpio. Jalacingo, Totoapan, Ventura 14792 (ENCB, MEXU, NY, XAL). NICARAGUA. Jinotega: mpio. Jinotega, Tuma Valle, Hacienda La Trampa, Cerro La Florida, Hawkes et al. 2150 (K). Matagalpa: al NW del Cerro Musún, sobre el filo de la montaña, en el área faldar, a partir trocho a Paylo, Araquistain \& Moreno 2605 (BM); falda N del Cerro Musún, frente a trocha a Wanawás, Araquistain \& Moreno 2790 (MEXU). Zelaya: Comarca Waslala, 6.5 $\mathrm{km}$ al SE de Waslala, $13^{\circ} 16^{\prime} \mathrm{N}, 8^{\circ} 24^{\prime} \mathrm{W}$, Moreno 17265 (MEXU); $2 \mathrm{~km}$ de Colonia Serrano, Comarca El Escobillo, Sandino 3307 (MEXU). Department Unknown: near Caño San Antonio, $2 \mathrm{~km} \mathrm{~N}$ of Kuikainita, Neill 4158 (BM). PANAMÁ. Chiriquí: Ojo de Agua, vic. of Santa Clara (between Volcán and Río Sereno), E of Volcán, 08 ${ }^{\circ} 51^{\prime} \mathrm{N}, 8^{\circ} 45^{\prime} \mathrm{W}$, Croat 66252 (MEXU); headwaters of Río Chevo, Finca Ojo de Agua, 08 $52^{\prime}$ N, 82 $44^{\prime}$ W, Knapp 1435 (MEXU); near Costa Rican border, ca. $13 \mathrm{rd} \mathrm{km}$ from Río Sereno, Finca Hartmann, 08 $50^{\prime} \mathrm{N}, 82^{\circ} 45^{\prime} \mathrm{W}$, McPherson 15962 (CAS, MEXU). Colón: Río Guanche, 09³0' N, 79³9' W, Sytsma 1697 (MEXU).

Urera verrucosa (Liebm.) V.W. Steinm., comb. nov. Urtica verrucosa Liebm., Kongel. Danske Vidensk. Selsk. Skr., 5.rk., Naturvidensk. Math. Afd. 2: 295. 1851.Type: Costa Rica. “in monte Irasu, 8000', 1/47," Ørsted 14284 (holotype C, not seen, photo!). 
Since first described by Liebmann, Urera verrucosa has subsequently been treated as a synonym of $U$. caracasana or in the case of Pool (2001) as a synonym of $U$. corallina. It is certainly very closely related to the latter species, and the differences between them are subtle and not always absolute. Notwithstanding some ambiguities, I believe that $U$. verrucosa is sufficiently distinct to warrant recognition. The most consistent of these is the possession of 5-merous staminate flowers that are in relatively loose clusters of ca. 6 to 12 . In U. corallina, the staminate flowers are 4-merous and numerous in dense, headlike clusters. In addition, the upper leaf surface of $U$. verrucosa is almost always bullate with the hairs situated on blisterlike protuberance of the epidermis. Liebmann's epithet "verrucosa" is in reference to this feature, and I have only rarely observed this trait in $U$. corallina. The upper leaf surface also possesses a more conspicuous reticulate network of tertiary and quaternary veins than is present in $U$. corallina. Although somewhat variable, the primary peduncle of the pistillate inflorescence in $U$. verrucosa is often elongated, (2)5$14 \mathrm{~cm}$ and usually equal to or longer than the floriferous portion of the inflorescence. In $U$. corallina the peduncle is shorter (rarely more than $3 \mathrm{~cm}$ long) and always exceeded in length by the floriferous portion of the inflorescence. Finally, the petioles of $U$. verrucosa characteristically possess numerous retorsely oriented urticating hairs, but such trichomes are generally absent in U. corallina.

In so far as I can determine, only the characteristic of 5-merous staminate flowers is definitive, and the other features are subject to exception. However, it is usually a single trait that varies for a given specimen, and viewed collectively the distinctions between these two species hold. Judging from label information, Urera verrucosa tends to occur at higher elevations and somewhat more mesic habitats than $U$. corallina. However, additional research is required to determine the extent of such habitat differences.

Urera verrucosa is widespread along both the Pacific and Atlantic slopes of Mexico and occurs south through Central America to at least Costa Rica. It grows primarily in canyons of cloud forest but rarely extends into mesic pine forest; 1200 $2800 \mathrm{~m}$. One specimen (Calzada et al. 3690) states that it is cultivated as a living fence.

Common names: chichicastle (Calzada et al. 3690), mala mujer (Nee \& Taylor 28880).

Specimens examined. COSTA RICA. Puntarenas: just E of Monteverde on the Pacific watershed, $10^{\circ} 18^{\prime} \mathrm{N}, 8^{\circ} 48^{\prime} \mathrm{W}$, Burger \& Baker 9608 (RSA). San José: Cantón del Aserrí, Tarbaca, 0950'32" N, 8406'55" W, Morales 1594 (NY). MEXICO. Chiapas: mpio. Unión Juárez, en el poblado de Unión Jaurez, Calzada et al. 3690 (XAL); mpio. Motozintla, Rancho Nuevo, $6 \mathrm{~km}$ al SE de El Rosario, Ventura \& López 2505 (CAS). Guerrero: mpio. Atoyac de Álvarez, 16 km, camino 
Puerto del Gallo-Atoyac de Álvarez, Millán 181 (ENCB). Hidalgo: mpio. Tenango

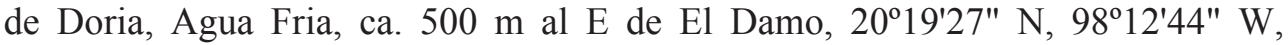
Alcántara 1116 (MEXU); mpio. Tenango de Doria, $6 \mathrm{~km}$ al E de Tenango de Doria, hacia al Cirio, Hernández 5470 (MEXU). Jalisco: Sierra de Manantlán, senderos desde Arroyo El Chilacayote (tributario del Arroyo Las Joyas) al cerrito central de Cerro La Piedra Bola de los mapas, 2-3.5 km al NE de la Estación Biológica "Las Joyas," ca. 9-11 km al SE de Ahuacapán, Judziewicz et al. 4943 (IBUG); mpio. Autlán, Estación Científica las Joyas, Cañada del Tlacuache, Cuevas \& Guzmán 4398 (ARIZ, ENCB). Edo. de México: Ocuilan, terracería Cuernavaca-Ocuilán, $4 \mathrm{~km}$ al O de Ahuatenco, Koch 834 (ENCB, NY, XAL). Michoacán: mpio. San Juan Nuevo Parangaricutiro, Cañada La Culebra, Medina G. 2859 (IEB). Morelos: Cuernavaca, Hinton et al. 17066 (ENCB, IEB, K, MEXU); mpio. Cuernavaca,

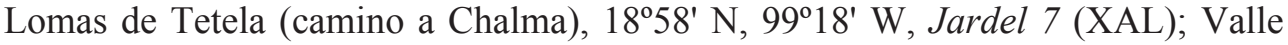
del Tepeite, Lyonnet 1350 (MEXU); Barranca de Atzingo, Vázquez 3587 (MEXU). Oaxaca: distr. Teotitlan, $26.1 \mathrm{~km} \mathrm{~W}$ of Teotitlan del Camino, Bartholomew 3183 (CAS, MEXU); distr. Ixtlán, mpio. Comaltepec, SW slope of Cerro Relámpago, just above (N of) Río Soyolapan, 17²2'15" N, 96²4'05" W, Boyle et al. 2668 (MEXU); distr. Juxtlahuaca, mpio. Santiago Juxtlahuaca, 1-2 km del poblado El Manzanal, carr. a Infiernillo, 17013'29" N, 98 03"49" W, Calzada 21570 (MEXU); distr. Miahuatlán, mpio. San Jerónimo Coatlán, 11.7 km al SW de San Jerónimo Coatlán, $16^{\circ} 21^{\prime}$ N, 96 $6^{\circ} 57^{\prime}$ W, Campos 938 (MEXU); mpio. Santa Lucía M., $32 \mathrm{~km}$ al S de Miahuatlán, sobre la terracería a Pochutla, Koch \& Fryxell 78391 (NY); Puerto de La Soledad, 14 IV 1964, MacDougall s. n. (MEXU); San Juan Guivini, MacDougall 7938 (MEXU); distr. Miahuatlán, 13.7 km al SE de San José del Pácifico, Torres 2754 (MEXU); Torres 10816 (MEXU); distr. Juchitán, mpio. Tapanatepec, 2.6 km al $\mathrm{N}$ de Rodolfo Figueroa, camino a Díaz Ordaz, entrando por Rizo de Oro, 163'00" N, 94¹1'00" W, Torres 10593 (MEXU). Puebla: Tlatlauqui, Boege 1708 (MEXU); mpio. Zochitlan, Talcozuman, Ventura 22362 (IEB, XAL). Querétaro: Río Escanelilla, $1 \mathrm{~km}$ al S de Escanelilla, sobre la carr. a Pinal de Amoles, municipio de Pinal de Amoles, Pérez et al. 3723 (IEB); La Cuesta, $3 \mathrm{~km}$ al S de Escanelilla, municipio de Pinal de Amoles, Fernández \& Acosta 2185 (ENCB). Veracruz: mpio. Yecuatla, Sierra de Chiconquiaco, Cañada del Huérfano, carr. XalapaMisantla, 1948' N, 96 ${ }^{\circ} 50^{\prime}$ W, Calzada 7897 (ENCB, MEXU); Xalapa, Galeotti s. n. (K); mpio. Yecuatla, Cerro Villa Rica, arriba del Cedral, $19^{\circ} 48^{\prime} \mathrm{N}, 9^{\circ} 45^{\prime} \mathrm{W}$, Gutiérrez 3417 (XAL); Huatusco, Linden 40 (K); mpio. Calcahualco, Escola, camino a Xamaticpac, barranca del Río Jamapa, 1909' N, 97 06' W, Martínez \& Vázquez 494 (XAL); Misantla, VI 1866, Hahn s. n. (P); mpio. Xico, La Pandura, camino del Ingenio El Rosario a Xico, 19³0' N, 97º5' W, Narave et al. 343 (MEXU); mpio. Xico, gorge at Puente Acabaloya, ca. $1 \mathrm{~km} \mathrm{SE}$ of Xico Viejo and $5 \mathrm{~km} \mathrm{NW}$ of Xico along trail between two, $19^{\circ} 27^{\prime} \mathrm{N}, 97^{\circ} 03^{\prime} \mathrm{W}, 1600 \mathrm{~m}$, Nee \& 
Taylor 26275 (XAL); mpio. Huatusco, $1 \mathrm{~km} \mathrm{NW}$ of Elotepec along (impassable) rd to Chichiquila, $19^{\circ} 12^{\prime} \mathrm{N}, 97^{\circ} 02^{\prime} \mathrm{W}$, Nee \& Taylor 28880 (NY, XAL); $5 \mathrm{~km} \mathrm{NW}$ of Zongolica on rd from Orizaba, Solheim \& Reisfield 1456 (MEXU, XAL).

\section{ACKNOWLEDGEMENTS}

I thank the curators and staffs at the following institutions for permiting access to their collections: BM, CAS, DS, ENCB, IBUG, IEB, K, MEXU, NY, P, POM, RSA, UC, UCR, XAL, and ZEA. Alex Monro (BM) provided many useful comments and much assistance during preparation of the manuscript, and I greatly appreciate his help. Paul Fryxell critically reviewed the manuscript. William R. Anderson and Rogers McVaugh (MICH) kindly granted permission to use an unpublished drawing from Flora Novo-Galiciana. Rogelio Cárdenas drew the illustration of Urera rzedowskii. Vanessa Ashworth, editor of Aliso, provided technical assistance with editorial tasks. Economic support was provided by a grant from the Comisión Nacional para el Conocimiento y Uso de la Biodiversidad to the Instituto de Ecología, A.C.

\section{LITERATURE CITED}

Adams, C. D. 1972. Urticaceae. In: Flowering plants of Jamaica. University of the West Indies, Mona. pp. 225-238.

Berg, C. C. 1992. Urticaceae. In: A. R. A. Gorts-van Rijn (ed.). Flora of the Guianas, Ser. A, 11. Koeltz Scientific Books, Koenigstein. pp. 125-139.

Burger, W. 1977. Flora Costaricensis, Urticaceae. Fieldiana, Bot., n.s. 40: 218-283.

Fawcett, W. and A. B. Rendle. 1914. Urticaceae. In: Flora of Jamaica, vol. 3. British Museum, London. pp. 55-85.

Friis, I. 1993. Urticaceae. In: K. Kubitzki, J.G. Rohwer, and V. Bittrich (eds.). The families and genera of Vascular Plants II. Flowering plants. Dicotyledons. Magnoliid, Hamamelid and Caryophyllid families. Berlin and Heidelberg: Springer-Verlag. pp. 612-630.

Killip, E. P. 1960. Flora of Panama (Urticaceae). Ann. Missouri Bot. Gard. 47: 179-198.

Pool, A. 2001. Urticaceae. In: W.D. Stevens, C. Ulloa, A. Pool, and O.M. Montiel (eds.). Flora de Nicaragua; Monographs in Systematic Botany from the Missouri Botanical Garden 85. Missouri Botanical Garden Press, St. Louis. pp. 2479-2495.

Puig, H. 1993. Árboles y arbustos del bosque mesófilo de montaña de la Reserva El Cielo, Tamaulipas, México. Instituto de Ecología, Xalapa. pp.

Standley, P. C. 1922. Urticaceae. In: Trees and shrubs of Mexico. Contr. U.S. Natl. Herb. 23: $218-221$.

Standley, P. C. and J. C. Steyermark. 1952. Flora of Guatemala, Urticaceae. Fieldiana, Bot., n.s. 24(3): 396-430. 
Weddell, H. A. 1856. Monographie de les urticacées. Arch. Mus. Hist. Nat., Paris 9: 1592.

Weddell, H. A. 1869. Urticaceae. In: A. de Candolle (Ed.), Prodromus systematis naturalis regni vegetabilis. Paris: Masson et fils. 16(1): 32-235/64.

Recibido en octubre de 2004.

Aceptado en marzo de 2005. 